\title{
Commentary
}

\section{A Call for Routine HIV Testing Among Patients with Hepatitis C Virus Infection}

\author{
Lynn E. Taylor ${ }^{*}, 1,2$, Melissa M. Gaitanis ${ }^{1,3}$ and Curt G. Beckwith ${ }^{1,2}$ \\ ${ }^{1}$ The Warren Alpert Medical School of Brown University, Providence, RI 02906, USA \\ ${ }^{2}$ The Miriam Hospital, Providence, RI 02906, USA \\ ${ }^{3}$ Providence VA Medical Center, Providence, RI 02908, USA
}

In February 2010, Mr. R, a 49-year-old male with wellcontrolled HIV infection on highly active antiretroviral therapy (HAART), was referred to our HIV/viral hepatitis coinfection clinic for evaluation of chronic hepatitis $\mathrm{C}$ virus (HCV) infection. While he was worried about the degree of damage to his liver and whether $\mathrm{HCV}$ treatment was indicated, his greatest concern was for his wife. The couple had been having unprotected intercourse since they were teenagers, and Mr. R feared that his 47-year-old wife was infected with HIV. Mrs. R was diagnosed with chronic HCV years earlier and was under the care of a highly regarded gastroenterologist. This physician recommended liver biopsy with pharmacotherapy for HCV but had not tested Mrs. R for HIV.

Mrs. R. tells her husband that she would rather die than know that she is coinfected with HIV. She has been aware of his HIV status since his diagnosis in 1986. Initially she declined to talk with us but two months later agreed to be evaluated for a second opinion regarding HCV. At this visit, a rapid HIV test was positive. Further evaluation confirmed her HIV infection. With $\mathrm{CD}^{+}{ }^{+}$cell count of 398 cells/uL; the presence of HCV coinfection; genotype 1a virus; and reassuring physical exam, liver function tests and platelet count, she initiated HAART and deferred liver biopsy and HCV treatment consideration until she adjusted to her HIV diagnosis.

This is an all-too common scenario -- a patient thought to be HCV-monoinfected is engaged in medical care for an infection which shares routes of transmission with HIV -but is not tested for HIV. Missed HIV diagnosis may lead to misinformed treatment decisions with poorer outcomes for both HIV and HCV, because dual infection alters management of both diseases. HIV can accelerate $\mathrm{HCV}$ disease course, with more rapid progression to cirrhosis, liver failure and hepatocellular carcinoma in coinfection. $\mathrm{HCV}$ infection is the most frequent cause of non-AIDSrelated death for $\mathrm{HIV}$-infected persons with access to HAART [1, 2]. HCV treatment leading to a sustained virologic response (SVR) reduces liver-related mortality and

*Address correspondence to this author at the Warren Alpert Medical School of Brown University, The Miriam Hospital, Center for AIDS Research (CFAR) Building 156, 164 Summit Avenue, Providence, RI 02906, USA; Tel: (401) 793-4705; Fax: (401) 793-4709;

E-mail: 1taylor@lifespan.org morbidity in coinfection [3], and national and international guidelines endorse considering all coinfected patients for $\mathrm{HCV}$ treatment [4-6]. However, patients require closer monitoring during $\mathrm{HCV}$ treatment than in $\mathrm{HCV}$ monoinfection because adverse events are more common and severe.

Although coinfection increases risk of HAART-related hepatotoxicity, liver disease progression is slower in patients receiving HAART, and benefits outweigh risk. Irrespective of $\mathrm{CD}^{+}$cell count, HIV RNA level, HIV-related symptoms and other opportunistic infections, early HAART introduction is recommended to reduce the rate of progression of hepatic disease [7, 8]. In most cases, HAART should precede HCV treatment, to decrease HIV-related morbidity and mortality, and diminish HIV transmission.

In this issue of The Open Infectious Diseases Journal, Fuller et al. add to the growing body of evidence supporting routine HIV testing for $\mathrm{HCV}$-infected veterans. Among a national sample of over 305,000 veterans with $\mathrm{HCV}$ infection, only one third were tested for HIV; of those tested, $13.2 \%$ were coinfected. These findings are consistent with earlier work demonstrating a substantial prevalence of HIV coinfection among $\mathrm{HCV}$-infected veterans, ranging from 5\%-25\%, and insufficient HIV co-testing [9-11].

The Veterans Health Administration (VHA) of the US Department of Veterans Affairs is the largest single provider of HIV, HCV and HIV/HCV care in USA [12]. The VHA has endorsed HIV testing for all patients with HCV since 2003 [13]. In 2009 the VHA issued a directive to incorporate HIV testing into routine medical care for all patients, with annual testing for those with ongoing risk.

Outside the VA, HIV prevalence in HCV-infected patients surpasses that of the general population, and prevalence of undiagnosed HIV infection exceeds the threshold that makes routine testing cost-effective [14-16]. The American Association for the Study of Liver Diseases proposes testing all $\mathrm{HCV}$-infected persons with HIV risk factors for HIV [4]. However, HIV testing based on clinicians' impression of patients' HIV risk has been found to be inadequate, and the Centers for Disease Control and Prevention advocates routine voluntary HIV screening as a usual part of medical practice [16]. Certainly this should encompass universal opt-out HIV testing for all HCV- 
infected patients [15], who need to be recognized as a priority group for HIV screening.

\section{ACKNOWLEDGEMENTS}

Partial support for this publication was provided by grants K23DA020383 and K23DA021095 from the National Institute on Drug Abuse, National Institutes of Health (NIDA/NIH) and grant number P30AI42853 from the National Institutes of Health, Center for AIDS Research (NIH/CFAR). The content is solely the responsibility of the authors and does not necessarily represent the official views of the National Institute on Drug Abuse or the National Institutes of Health.

\section{POTENTIAL CONFLICTS OF INTEREST}

L. Taylor: Grant support from Roche and Vertex, Speakers' Bureau for Genentech, has received consulting fees from Vertex.

\section{REFERENCES}

[1] Weber R, Sabin CA, Friis-Moller N, et al. Liver-related deaths in persons infected with the human immunodeficiency virus: the D: A: D study. Arch Intern Med 2006; 166(15): 1632-41.

[2] Monga HK, Rodriguez-Barradas MC, Breaux K, et al. Hepatitis C virus infection-related morbidity and mortality among patients with human immunodeficiency virus infection. Clin Infect Dis 2001; 33(2): 240-7.

[3] Berenguer J, Alvarez-Pellicer J, Martin PM, et al. Sustained virological response to interferon plus ribavirin reduces liverrelated complications and mortality in patients coinfected with human immunodeficiency virus and hepatitis $\mathrm{C}$ virus. Hepatology 2009; 50(2): 407-13.

[4] Ghany M, Strader D, Thomas D, Seeff L. Diagnosis, management, and treatment of hepatitis C: an update. Hepatology 2009; 49(4): $1335-74$.
[5] Soriano V, Sulkowski M, Bergin C, et al. Care of patients with chronic hepatitis $\mathrm{C}$ and HIV co-infection: recommendations from the HIV-HCV International Panel. AIDS 2002; 16(6): 813-28.

[6] NIH Consensus Statement on Management of Hepatitis C: 2002, NIH Consens State Sci Statements 2002; 19(3): 1-46.

[7] Thompson MA, Aberg JA, Cahn P, et al. Antiretroviral treatment of adult HIV infection: 2010 recommendations of the International AIDS Society-USA panel. JAMA 2010; 304(3): 321-33.

[8] Brau N, Salvatore M, Rios-Bedoya CF, et al. Slower fibrosis progression in HIV/HCV-coinfected patients with successful HIV suppression using antiretroviral therapy. J Hepatol 2006; 44(1): 4755.

[9] Huckans MS, Blackwell AD, Harms TA, Indest DW, Hauser P. Integrated hepatitis $\mathrm{C}$ virus treatment: addressing comorbid substance use disorders and HIV infection. AIDS. 2005; 19(Suppl 3): S106-15.

[10] Bini EJ, Currie SL, Shen H, et al. National multicenter study of HIV testing and HIV seropositivity in patients with chronic hepatitis C virus infection. J Clin Gastroenterol. 2006; 40(8): 7329.

[11] Brau N, Bini EJ, Shahidi A, et al. Prevalence of hepatitis C and coinfection with HIV among United States veterans in the New York City metropolitan area. Am J Gastroenterol 2002; 97(8): 2071-8.

[12] Backus LI, Boothroyd D, Deyton LR. HIV, hepatitis C and $\mathrm{HIV} /$ hepatitis $\mathrm{C}$ virus co-infection in vulnerable populations. AIDS 2005; 19 Suppl 3: S13-9.

[13] Department of Veterans Affairs. VA treatment recommendations for patients with chronic hepatitis $\mathrm{C}$ (version 5.0). Federal Practitioner 2003; 20(Suppl 5 ): 1-33.

[14] Krain A, Wisnivesky JP, Garland E, McGinn T. Prevalence of human immunodeficiency virus testing in patients with hepatitis B and C infection. Mayo Clin Proc 2004; 79(1): 51-6.

[15] Geretti AM, Madge S, Posner M, Dusheiko G, Jacobs M. Missed opportunities: Undiagnosed HIV infection in patients with viral hepatitis. BMJ 2008; 336(7659): 1451-2.

[16] Branson BM, Handsfield HH, Lampe MA, et al. Revised recommendations for HIV testing of adults, adolescents, and pregnant women in health-care settings. MMWR Recomm Rep 2006; 55(RR-14): 1-17; quiz CE1-4.

(C) Taylor et al.; Licensee Bentham Open.

This is an open access article licensed under the terms of the Creative Commons Attribution Non-Commercial License (http://creativecommons.org/licenses/ by-nc/3.0/) which permits unrestricted, non-commercial use, distribution and reproduction in any medium, provided the work is properly cited. 